\title{
THE
}

$12-8-2011$

\section{ACRL New England Scholarly Communication Special Interest Group Workshop: Open Access and Scholarly Societies: A Panel Discussion About the Opportunities and Challenges}

Andrée J. Rathemacher

University of Rhode Island, andree@uri.edu

Follow this and additional works at: https://digitalcommons.uri.edu/lib_ts_pubs

Part of the Library and Information Science Commons

Citation/Publisher Attribution

Rathemacher, Andrée J.. "ACRL New England Scholarly Communication Special Interest Group Workshop: Open Access and Scholarly Societies: A Panel Discussion About the Opportunities and Challenges." , (2011). doi: 10.1016/j.serrev.2012.05.007.

This Article is brought to you for free and open access by the Technical Services at DigitalCommons@URI. It has been accepted for inclusion in Technical Services Department Faculty Publications by an authorized administrator of DigitalCommons@URI.For more information, please contact digitalcommons-group@uri.edu. 


\section{ACRL New England Scholarly Communication Special Interest Group Workshop: Open Access and Scholarly Societies: A Panel Discussion About the Opportunities and}

Challenges

Andrée J. Rathemacher

This report covers a workshop held by the Scholarly Communications Interest Group (SCIG) of the Association of College and Research Libraries New England Chapter (ACRL/NEC), an independent chapter of ACRL. The workshop, titled "Open Access \& Scholarly Societies: A Panel Discussion About the Opportunities and Challenges," took place on November 18, 2011 at the Hoagland-Pincus Conference Center in Shrewsbury, Massachusetts.

\section{Scholarly Society Speakers}

Moderator October Ivins of the consulting firm Informed Strategies introduced the first segment of the panel discussion, which featured two speakers from scholarly societies. The first panelist was Robert Kelly, director of Journal Information Systems at the American Physical Society (APS), which publishes the Physical Review. Kelly stated that the objective of the APS is "the advancement and diffusion of the knowledge of physics," and that for some time the APS has been questioning how to best accomplish this objective. As early as 1968, editor S.A. Goudsmit recognized that the Physical Review was no longer a means of communication among active physicists, because by the time an article is published in the journal, "all relevant information is known to almost all concerned" through the use of preprints. In 1991 an APS task force 
produced a report on electronic information systems; this report envisioned a World Scientific Information System that would make all the world's formal scientific literature available online, a goal referred to as "Vision 2020." Kelly was hired by APS in 1993 to work toward realizing this vision.

Open access and Creative Commons licensing have become important strategies in moving toward implementation of Vision 2020, beginning with APS's recognition in the 1990s that eprints (online preprints) were a legitimate component of the scholarly communications process. In November 2009, the APS Council adopted a Statement on Open Access that supported the principles of open access "to the maximum extent possible that allows the Society to maintain peer-reviewed high-quality journals, secure archiving, and the Society's long-term financial stability, to the benefit of the scientific enterprise." Kelly commented that, unfortunately, much of the STM ecosystem is still supported by the subscription model, and if a shared understanding of open access does not emerge, there is a danger that the current system will be destroyed.

Since 1994, the APS has been taking incremental, sustainable steps toward making the scientific literature of physics more widely available. They re-engineered their peer-review and manuscript production process from paper-based to online, began composing journals in SGML, XML, and MathML so that content could be repurposed as needed (which reduced their composition costs from more than $\$ 70$ to less than $\$ 30$ a page), and digitized their journal back files. The number of journals published by the APS increased from seven to ten, and the number of articles submitted and published each year between 1994 and 2010 increased by 74 and 54 
percent respectively. APS introduced tiered pricing in 2001 in response to a decline in multiple institutional subscriptions as subscriptions were converted to online-only site licenses, however they were able to offer two general price reductions in 2005 and 2009. Because of these changes, institutions now receive more content per dollar than ever before.

APS has also made strides in open access (OA). They have allowed green OA since 1994, and their permissions have become more liberal over time. Authors may post pre-prints of their manuscripts in repositories and may post the APS-formatted version upon publication, with no embargo. APS allows authors to create derivative works using up to 50 percent of any article published in their subscription-based journals. Since 2006, six subscription-based journals the Physical Review titles and Physical Review Letters - have been published under a hybrid model, whereby authors may pay to make their articles available open access, though the percentage of articles published open access in these titles in 2010 remained under two percent. In addition, APS has introduced three gold OA journals that provide immediate open access to all articles. One title is sponsored by a laboratory, and the other two are primarily funded by author fees, though APS provides annual subsidies to all three titles to help defray costs. All APS hybrid and gold OA titles are published under a Creative Commons Attribution license (CC BY), which is the most accommodating Creative Commons license and is "recommended for maximum dissemination and use of licensed materials." (http://creativecommons.org/licenses/).

Upcoming goals in the pursuit of Vision 2020 include working to integrate data into publications, developing interactive content, implementing author and institution identifiers, 
making complex mathematical content more accessible for print-disabled users such as the blind, and employing semantic tagging to link together topics across disciplines. One workshop participant asked why physics is so far ahead of other disciplines with regard to open access. Kelly responded that acceptance of open access is discipline-specific, even in physics. Scientists in applied areas of physics often have concerns about patentable discoveries and are less supportive of open access than theoretical physicists. The APS supports open access, but physics as a discipline, does not necessarily.

The next speaker was Ken Heideman (director of publications, American Meteorological Society (AMS)) who explained that the AMS defines open access as free online access without the need for a subscription and that the AMS insists on maintaining copyright of articles published in their journals so that they can act as a steward of authors' intellectual property. The AMS publishes eleven peer-reviewed journals, comprising 1,700 manuscripts and 26,000 pages per year. The AMS is much smaller than the APS, but their goals are similar.

The AMS is moving incrementally toward open access for their publications. In 1998, no AMS journal content was open access; in the early 2000s, content older than five years was made open access, and in 2008 the moving wall for open access articles was lowered to two years. Content published more recently is available only by subscription. Authors may post the final published PDF version of their articles to an institutional repository six months after publication because the AMS only wants one version of each article available - the official version. Unlike the other AMS journals, all articles published in the Bulletin of the American Meteorological Society, the 
official organ of the AMS, are available open access with no embargo. This has been the case since 1997, though some content, such as professional and membership news and society activities, is available only to members.

The American Meteorological Society's business model for journal publishing is balanced between subscription income and author charges, which make up 43 and 57 percent of income respectively. The AMS is trying to slowly shift this balance more toward author charges to reduce the barrier of subscription-based access. For now, the combination of subscription and author charge income allows for waivers of these charges for authors whose institutions cannot pay, paid clerical support for volunteer editors, high editorial quality for the journals, and longterm stewardship of the content.

Heideman explained that despite their continued reliance on subscription income, AMS subscriptions are among the most affordable in science, costing only $\$ 0.15$ a page for institutions and $\$ 80$ per year for members. The society participates in OARE (Online Access to Research in the Environment), which provides access in developing countries to environmental science research, and the AMS will provide free access to their journals to any developing world institution on request. In May 2012, the AMS plans to offer a hybrid publication model. Individual authors will be able to pay for immediate open access to their articles at a rate lower than most publishers charge for this option. The income from this initiative will be used to lower subscription costs for libraries. 
While facilitating a brief question-and-answer session with the scholarly society speakers, Ivins noted that both speakers represented professional societies with large staffs, which is not typical. More common are societies with ten to twenty staff members, only a few of whom are involved in publishing activities. These smaller societies frequently do not self-publish as the APS and AMS do but contract with commercial publishers such as Elsevier or Springer. One workshop participant asked the speakers what kind of feedback they received from society members and editors about their efforts to move in the direction of open access. Kelly responded that the APS supported open access not for the purpose of promoting it, per se, but because it was what their community wanted to do. Open access is not the goal; the widest possible dissemination of content is the goal, as well as being able to connect and reuse content, which is only possible when content is freely available. Another attendee asked about the speakers' views on publishing hybrid open-access journals in the context of the Compact for Open-Access Publishing Equity (COPE). Institutions that have endorsed COPE will pay author fees for faculty to publish in fully open access journals, but not in hybrid journals that also collect a subscription fee. Heideman responded that authors have required that their articles be published open access but have not requested that an entire AMS journal be published open access. In the end, the publication process has to be sustainable, and the AMS is still working on a funding model that would support full OA. Kelly echoed Heideman's response, explaining that the APS has a large staff working to support their journal publishing activities. Transitioning to gold OA for all APS journals is simply not financially possible at this time. 


\section{Faculty Speakers}

The second segment of the panel discussion, highlighting the faculty perspective, began with Steven Zinn (professor of animal science, University of Connecticut). Zinn is editor-in-chief of the Journal of Animal Science and editor of Animal Frontiers: The Review Magazine of Animal Agriculture, the two periodicals published by the American Society of Animal Science (ASAS). He stated that the ASAS is one society with two publication models based on the different missions of their journals.

The Journal of Animal Science is the society's peer-reviewed research journal, containing scholarship on the sustainable use of animals for food and other human needs. Its primary audience is the membership of the ASAS, which consists mostly of animal science researchers located at land-grant universities and in agriculture industry laboratories, plus graduate and undergraduate student members. Access to recent articles is restricted to ASAS members and institutional subscribers; all articles become open access after one year. The Journal of Animal Science is funded by page charges of $\$ 85$ for members and $\$ 170$ for nonmembers, by institutional subscriptions, and by a $\$ 100$ surcharge for print subscriptions. As an alternative to page charges, authors may choose an open access option whereby members pay $\$ 2,500$ and nonmembers $\$ 3,250$ to make an article open access immediately upon publication. Authors may self-archive their post-prints in an institutional repository only when mandated to do so by a funding agency or employer, and only twelve months after publication. 
The other peer-reviewed periodical published by the ASAS, Animal Frontiers, follows a purely open access model. Animal Frontiers is a joint venture between the ASAS, the Canadian Society of Animal Science, and the European Federation of Animal Science and was first published in July 2011. The primary audience for this publication is policy-makers and other non-scientists. Each issue is theme-based, covering topics like global beef production, water use, and animal welfare. All articles are invited, and authors are paid for their contributions to encourage fast turn-around. Animal Frontiers is distributed electronically to approximately 70,000 individuals and organizations including society members, people working in the agricultural industry, government officials, and deans and department heads at universities. Zinn explained that the societies that founded Animal Frontiers chose the open access model because they wanted the widest possible distribution for the publication, well beyond the memberships of the three societies. To fund start-up costs for the publication, each founding member pledged between $\$ 20,000$ and $\$ 35,000$. In addition to funding from these foundational sponsors, Animal Frontiers accepts advertising and receives support from sustaining partners. There are also a small number of subscribers who pay for print subscriptions.

After Zinn's presentation, an audience member again raised the issue of COPE, which disallows institutional support for author fees in hybrid journals like the Journal of Animal Science. Zinn responded that he finds COPE “ridiculously offensive." In its field, the Journal of Animal Science is the number one journal based on impact factor; purely open access journals eligible for COPE funds often do not even have impact factors. With COPE, libraries are deciding in which journals authors should publish, and this is not appropriate. It is also not appropriate for provosts to value articles for tenure decisions based on the fact that the articles appear in open 
access journals. Zinn feels that with COPE, librarians and other non-scientists are determining where researchers should publish their work, and as a result, researchers will be penalized when they apply for promotion and tenure because their articles appeared in open access journals with less impact and prestige.

The second faculty speaker was Michael James (fellow, Roche Center for Catholic Education, Boston College), co-editor of the open access research journal Catholic Education, and book review editor for the forthcoming open access journal Claritas. James told the audience that he wanted to present a fairy tale, a "real-life love story between a struggling journal and its librarians."

In 1997, the quarterly journal Catholic Education was founded by the schools of education at four Catholic universities to provide a publishing forum for scholars interested in the purposes, practices, and issues in Catholic education from kindergarten through higher education. Authors writing on this topic had been finding that if they included the word "Catholic" in their articles, competitive, peer-reviewed education journals were not accepting their work.

During the first fourteen years of the journal's existence, it operated under a traditional, subscription-based model, reaching a peak of 700 subscribers. After this peak three to five years ago, the number of subscribers started to decline. In response, the journal's governing board implemented new methods and approaches to marketing the journal, but these efforts to increase 
the subscriber base were unsuccessful. Enthusiasm for the journal began to wane among the institutions providing its support, and presidents and provosts balked at continuing to subsidize the journal without evidence of its impact. At the same time that the journal's subscriber base was declining, the quality of submitted manuscripts was deteriorating, and acceptance rates were going up. These trends threatened the life of the journal.

Every five years, a different institution on the twenty-two-member governing board of Catholic Education assumes editorial responsibilities and primary financial support for the journal. Three years ago, these responsibilities fell to Boston College, and the editorial team there did not want Boston College to be remembered as the institution that "killed" the journal. They turned to their campus librarians for advice. The librarians suggested an open access model, and after the governing board approved the change, Catholic Education became open access in 2010. After six months publishing both online and in print, the journal transitioned to online-only in January 2011.

James commented that one of the great advantages of the open access, online-only model has been the ability to track downloads of articles. During the first fourteen years of the journal's existence, total distribution was about 40,000 issues, whereas in the first ten months of publishing as an open access journal, the number of articles downloaded totaled 101,625. James feels that converting Catholic Education to open access in partnership with the Boston College library has brought new life to the journal, as in the fairy tale when the princess kisses the frog and he turns into a prince. 
Kent Holsinger, who spoke to the audience via Skype, was the final faculty panelist. Holsinger holds the rank of professor in the Department of Ecology and Evolutionary Biology at the University of Connecticut and is the current chair of the Board of Directors at BioOne. He is a member of the editorial board of BioScience and an associate editor of the Quarterly Review of Biology, as well as having served in 2009-2010 as president of the Botanical Society of America.

Holsinger noted that the first scholarly society, the Royal Society of London, was founded over 350 years ago "to discuss the new philosophy of promoting knowledge of the natural world...science." The first issue of the Philosophical Transactions of the Royal Society noted that, "[T]here is nothing more important...than communicating...such things as are discovered." This idea, said Holsinger, is the foundation and purpose of scholarly societies- to communicate what is discovered and to support discovery. Scholarly societies communicate scholarly work through scholarly journals and scholarly meetings. They also support young scholars from kindergarten through graduate education, issue small grants, and garner support for their field by engaging in public outreach and conversations around public policy. All of these activities require that scholarly societies have adequate revenue to support their operations.

Although the specifics of societies' revenue streams differ from society to society, in general, scholarly societies are supported by individual member dues, institutional journal subscriptions, government and foundation grants, and private philanthropy and endowment income. Institutional journal subscriptions typically contribute significantly to society income, despite the 
fact that most self-published society journals cost far less than comparable journals from forprofit commercial publishers.

The costs of publishing a society journal tend to be low, but they must be covered. Reviewers are generally unpaid, and editors are often unpaid or receive a nominal stipend. Typically, only about 30 percent of the costs of publishing are associated with producing a journal in print format, so even if a society chooses to publish online-only, 70 percent of its publishing costs will remain. Open access presents a dilemma for scholarly societies. On the one hand, open access is consistent with their mission to disseminate scholarship as broadly as possible. On the other hand, societies need to cover the costs of publication as well as support their other activities, which are essential for promoting the health of the fields they represent. Fortunately, there are intermediate models, and BioOne is one example. BioOne is a not-for-profit journal aggregator that seeks to provide a fair price to libraries while still offering substantial income to society publishers. Though BioOne is subscription-based, it includes twelve open access titles.

In response to a question from the audience, Holsinger commented that membership in scholarly societies has been in decline since society journal content became available online, primarily through academic library site licenses. Because scholars can easily access society publications electronically, they no longer feel the need to maintain their society memberships. Another attendee countered that many types of organizations have been experiencing declines in membership, not just scholarly societies, so online access to society journals cannot be the entire explanation. It is a problem that scholarly societies have become dependent on institutional 
subscriptions to support their activities; they are relying on other organizations-libraries and universities - to support their missions. Holsinger agreed that there has been some degree of complacency among scholarly societies in searching for new income models, but most scholarly societies are run almost entirely by volunteers, namely faculty members with full-time jobs. He pointed out that there simply are not enough hours in the day to think creatively about alternative business models, and that most scholarly society journals are still very affordable for libraries compared to journals from commercial publishers. If these societies ceased to exist, libraries would have to pay more to access the same content. Libraries are getting good value for their money.

In a final question, the panelists were asked to look to the future and share their thoughts on whether or not journals as we know them will still exist and whether libraries will continue to pay for them. Holsinger responded first, stating that he found it difficult to imagine a future where something more or less equivalent to the journal did not exist because academia is conservative and peer review and publication will continue to play a role in certifying the quality of research results, especially with regard to promotion and tenure decisions. What remains to be seen is whether journals will follow a subscription model in which libraries are consumers, or an open access, author-pays model in which libraries help with publication. Regardless, universities will have to take measures to ensure that the work of their scholars remains available in the long term. 
Kelly added that peer review and the dissemination of research results into a corpus of literature have been worthwhile activities thus far, and they will continue if viable, though not in the form of the printed journal. James agreed with Holsinger that it is the role of academic institutions to develop new receptacles for peer-reviewed scholarship and that in the future these will be more interactive, dialogical, conversational, and multimedia-rich. Zinn echoed the idea that universities will need to contribute to the costs of disseminating scholarship, in whatever way this may be accomplished. The current model for supporting the communication of research must change in order for scholars to be heard, otherwise research and data will become irrelevant in public discourse and policy-making. Ivins concluded the panel discussion by commenting that the explosion of information has lead to more content, better and richer metadata, and greater discoverability. As a result, the editorial process, which guarantees that quality data will enter the information pipeline, is more important than ever before.

\section{Contact info:}

\section{Andrée J. Rathemacher}

Professor

Head, Acquisitions

University Libraries, University of Rhode Island

15 Lippitt Road

Kingston, RI 02881-2011

Phone: (401) 874-5096

Fax: (401) 874-4588

E-mail: andree@uri.edu

http://www.uri.edu/library/ 